\title{
SISTEM EKONOMI ISLAM: SUATU PENDEKATAN FILSAFAT, NILAI-NILAI DASAR, DAN INSTRUMENTAL
}

\author{
Anwar Abbas*
}

\begin{abstract}
Islamic Economical System: A Phylosophy Approach, Basic Values, and Instrumental. Islamic economical system has its' own system. It is not a combination between capitalism and sosialism. Islamic economical system did not put human as a central (anthroposentrism) but as a God servant (âbid) that should serve and carry out the tasks entrusted to the servant (khaliffah). Therefore, the economic practice must uphold the values of ownership, the values of justice, freedom, balance, and in accordance with the fraternity and togetherness guided by religious teachings in order to create good personal living arrangements, social and national.
\end{abstract}

Keywords: Islamic economy, capitalist economy, socialist economy

\begin{abstract}
Abstrak: Sistem Ekonomi Islam: Suatu Pendekatan Filsafat, Nilai-nilai Dasar, dan Instrumental. Sistem ekonomi Islam adalah sistem ekonomi tersendiri, bukan merupakan perpaduan dan atau campuran antara sistem ekonomi kapitalis dan sosialis. Sistem ekonomi Islam menempatkan manusia bukanlah sebagai sentral (anthroposentrism) tetapi sebagai hamba Tuhan (âbid) yang harus mengabdi dan mengemban tugas yang dipercayakan-Nya sebagai hamba (khalîfah). Untuk itu, dalam kegiatan ekonomi harus menjunjung tinggi nilai-nilai kepemilikan, nilai-nilai keadilan, kebebasan, keseimbangan, dan persaudaraan serta kebersamaan sesuai dengan tuntunan ajaran agama agar tercipta sebuah tatanan hidup pribadi dan bermasyarakat serta bernegara yang baik.
\end{abstract}

Kata Kunci: ekonomi Islam, ekonomi kapitalis, ekonomi sosialis

Naskah diterima: 16 Januari 2011, direvisi: 12 Juli 2011, disetujui: 21 Juli 2011.

* Dewan Syariah Nasional Majelis Ulama Indonesia (DSN-MUI). Jl. Proklamasi No. 51, Menteng, Jakarta Pusat. E-mail: anwarabbas62@gmail.com 


\section{Pendahuluan}

Manusia mempunyai banyak kebutuhan. Zaman dahulu, ketika rumah tangga masih bersifat tertutup, kebutuhan manusia masih bersifat terbatas dan sederhana sehingga setiap keluarga menghasilkan sendiri produk-produk yang dibutuhkannya. Tetapi dengan semakin majunya tingkat peradaban, makin banyak dan bervariasi pula kebutuhan manusia. Usaha untuk memenuhi kebutuhan tersebut tidak lagi merupakan sesuatu yang sederhana. Akibatnya terjadilah ketidakseimbangan antara kebutuhan dan keinginan yang selalu meningkat dengan kemampuan manusia menyediakan alat pemuas bagi kebutuhan dan keinginan tersebut. ${ }^{1}$ Untuk itu, agar kemakmuran masyarakat dan individu tetap tercapai, maka muncullah beberapa sistem ekonomi. ${ }^{2}$

Abad XIX dan XX terdapat dua sistem ekonomi yang dominan yang menjadi kiblat bagi negara-negara di dunia yaitu sistem ekonomi kapitalisme dan sistem ekonomi sosialisme. Sistem kapitalisme murni, secara relatif, sudah tidak ada lagi dan hanya berlangsung selama 50 tahun pertama abad XIX. Sejak bagian kedua abad tersebut dan terlebih dalam abad XX sistem kapitalisme murni telah kehilangan wajahnya dan mengalami banyak perubahan sehingga timbullah apa yang dikategorikan dengan "kapitalisme historis" yang bentuk dan jenisnya disesuaikan dengan situasi, kondisi, waktu, tempat serta negara, dan masyarakat yang melaksanakannya.

Menurut Frans Seda ada tiga faktor yang menyebabkan dan mempengaruhi mengapa kapitalisme tidak dapat dilaksanakan secara murni di berbagai negara yang menerima atau menyetujui prinsip-prinsipnya, yaitu: timbulnya permasalahan sosial, timbulnya konsentrasi kekuasaan di pasar bebas, dan diperlukannya intervensi negara. ${ }^{3} \mathrm{Hal}$ itu menyebabkan di Amerika Serikat, yang menganggap dirinya sebagai negara kapitalis yang paling murni dan paling besar,

${ }^{1}$ Pandangan ekonomi konvensional menjelaskan bahwa kebutuhan manusia tidak terbatas sementara alat untuk pemuasnya terbatas sehingga muncullah masalah ekonomi yang disebut dengan scarcity (kelangkaan). Sedangkan dalam pandangan ekononi Islam (sebagian pakar) potensi sumber daya untuk itu cukup tersedia tetapi kemampuan manusia untuk mengolahnya terbatas sehingga timbullah masalah kelangkaan tersebut. Jadi, dalam pandangan ekonomi konvensional yang terbatas adalah sumber daya sementara dalam ekonomi Islam yang terbatas adalah kemampuan manusia untuk mengolahnya.

${ }^{2}$ Sistem ekonomi ialah seperangkat mekanisme dan lembaga untuk membuat dan melaksanakan keputusan mengenai produksi, pendapatan, dan konsumsi di dalam suatu wilayah tertentu. Lihat Ramlan Surbakti, Memahami Ilmu Politik, (Jakarta: Penerbit PT. Gramedia Widiasarana Indonesia), 1992, h. 207.

${ }^{3}$ Kompas, 15 September 1992. 
menunjukkan adanya deviasi-deviasi dari sistem ekonomi kapitalisme murni itu. ${ }^{4}$ Begitu juga di Jerman, menurut Didik J. Rachbini, negara tersebut menerapkan sosialis market ekonomi, yaitu suatu upaya pelunakan terhadap sistem ekonomi pasar sehingga mempunyai wajah lebih manusiawi. Sebuah inisiatif tidak dikekang agar dinamika masyarakat tumbuh secara optimal tetapi dipihak lain dituntut tanggung jawab sosial untuk meminimalkan bias yang negatif. ${ }^{5}$ Demikian pula halnya di negara-negara yang terkenal dengan sistem ekonomi sosialisme dan komunisme, di negara-negara tersebut terjadi proses transformasi dengan diserapnya sistem mekanisme pasar ke dalam sistem ekonomi mereka seperti terlihat di negara-negara Eropa Timur dan di Cina. ${ }^{6}$

Tetapi meskipun demikian kata Umar Chapra, "negara-negara ini (tetap) gagal pada berbagai tingkat untuk merealisasikan tujuan-tujuan yang hendak mereka capai. Banyak diantaranya yang menghadapi ketidakseimbangan makro ekonomi secara serius. Bahkan problem-problem yang harus mereka hadapi kian bertambah. Kekacauan sosial dan kejahatan juga meningkat, secara umum mereka menghadapi suatu situasi krisis."7 Mengapa hal itu masih terjadi? Chapra melihat hal ini sebagai sebuah konsekuensi alamiah dan dapat diperkirakan secara baik atas suatu cacat struktural yang inheren dalam sistem-sistem itu sendiri. Cacat-cacat itu timbul dari konflik dalam tujuan-tujuannya yang berakar pada moral dan agama pada masa lalunya dan pada pandangan dunia dan strateginya sebagai suatu basil dari sekulerisme dan cerminan sebuah pertentangan dengan tradisi-tradisi agamanya." 8

Untuk itu, menurut Chapra diperlukan pemikiran kembali sebuah fisafat yang benar tentang manusia. Hal ini juga dirasakan oleh para pemikir ekonomi kontemporer lainnya yang menyadari betapa pentingnya kajian ekonomi yang berkarakter religius, bermoral, dan humanis. Gunnar Myrdal misalnya dalam bukunya yang berjudul Asian Drama (1968), menyusun kembali ilmu ekonomi yang berkaitan dengan nilai-nilai kemanusiaan, baik perorangan, masyarakat

${ }^{4}$ Contoh deviasi tersebut diantaranya adalah adanya peraturan dan pengaturan yang tidak lagi rnemberikan kebebasan penuh kepada pemilikan perseorangan dan juga karena keterbatasannya sehingga kepemilikan pribadi tersebut semakin terdesak oleh kepemilikan oleh negara dan korporasi. Begitu juga motif profit yang mereka jadikan sebagai dasar pijakan dalam berusaha, terusik oleh adanya sistem perpajakan yang semakin rumit dan progresif dan adanya pembatasanpembatasan dalam persaingan seperti adanya Undang-undang anti-Trust, dll.

${ }^{5}$ Kompas, 20 Januari 1993, h. 4.

${ }^{6}$ Didik J. Rachbini, Ekonomi Politik, Paradigma, dan Teori Pilihan Publik, (Jakarta : Ghalia Indonesia, 2002)

${ }^{7}$ M. Umer Chapra, Islam dan Tantangan Ekonomi, Islamisasi Ekonomi Kontemporer, diterjemahkan Nur Hadi Ihsan dan Rifki Amar, (Surabaya: Risalah Gusti, 1999), Cet. I, h. 8.

${ }^{8}$ M. Umer Chapra, Islam dan Tantangan Ekonomi, h. 8. 
maupun bangsa. Hal yang sama juga dirasakan dan dilakukan oleh Eugene Lovell dalam bukunya, Humanomics, dan Schumacher dalam bukunya, Small Is Beautiful, Economics as if People Matered, dan terakhir oleh Joseph E. Stiglits, mantan anggota Dewan Penasihat Ekonomi Presiden Bill Clinton yang menulis buku, Globalization and its Discontents.

Para ekonomi ini menyadari bahwa meniadakan hubungan kajian ekonomi dengan nilai-nilai moral humanis adalah suatu kekeliruan besar dan mencerminkan sikap tidak bertanggung jawab dalam menjaga keselamatan manusia dan alam semesta. Untuk itu, di sinilah letak arti pentingnya mengkaji sistem ekonomi Islam yang oleh Taqiy al-Dîn al-Nabhânî dilihat sebagai sebuah sistem ekonomi alternatif. Paradigma dan nilai-nilai yang terdapat dalam sistem ekonomi ini berakar dan dikembangkan dari ajaran Islam yang bersumber kepada Alquran dan Sunah.

\section{Filsafat Ekonomi Islam}

Filsafat ekonomi merupakan orientasi dasar dari ilmu ekonomi yang dapat berlainan antara satu agama dengan agama lain, atau aliran dengan aliran lain karena kerangka referensi yang berbeda. Misalnya, orang-orang yang menganut filsafat kapitalisme masih percaya akan adanya Tuhan tetapi dalam keyakinannya, Tuhan setelah menciptakan alam dan meletakkan hukum-hukumnya tidak lagi ikut campur dengan urusan alam, termasuk dalam urusan ekonomi manusia. Semua persolan terserah kepada masing-masing individu. Oleh karena itu, manusia dalam pandangan filsafat ini memainkan peranan yang sangat sentral sehingga aliran ini bersifat antropocentrisme- individualisme. Paham antropocentrisme ini juga diyakini oleh faham marxisme-sosialisme tetapi bedanya mereka tidak percaya akan adanya Tuhan yang telah menciptakan alam dan tidak menekankan pentingnya individu, tetapi lebih mengutamakan kebersamaan atau kolektivitas. Bagi mereka semuanya adalah materi dan mereka tidak mengakui adanya sesuatu yang bersifat nonmateri. Oleh karena itu, paham mereka juga disebut dengan faham materialisme-sosialisme. Ini jelas berbeda dengan filsafat dan keyakinan yang terdapat dalam ajaran Islam.

Islam meyakini bahwa alam semesta ini berikut dengan isinya termasuk manusia adalah diciptakan oleh Allah Swt. (Q.s. al-Fâtihah [1]: 2), "Tuhan Yang Maha Pencipta dan Mahakuasa tersebut telah menunjuk manusia sebagai khalifah-Nya di muka bumi (Q.s. al-Baqarah [2]: 30). Ini artinya manusia telah ditunjuk menjadi "wakil dan manajer Tuhan di muka Bumi". Oleh karena itu, manusia berkewajiban untuk berbuat, termasuk di dalam mengelola alam ini dan atau melakukan tindakan ekonomi, sesuai dengan keinginan dan ketentuan 
yang telah ditetapkan oleh yang diwakilinya dan melaporkan serta mempertanggungjawabkan segala perbuatannya tersebut kepada Komisaris Besar tersebut (Allah Swt.) di hari kemudian (Q.s. al-Baqarah [2]: 202).

Untuk itu, sebagai khalifah manusia harus tahu garis-garis besar dan pedoman yang telah dibuat dan ditetapkan-Nya yang terdapat dalam Kitab Suci dan Sunah Rasul-Nya (Q.s. al-Baqarah [2]: 2).

\section{Nilai-nilai Dasar Sistem Ekonomi Islam}

Implikasi dari filsafat dan keyakinan di atas tentu akan melahirkan sejumlah nilai dasar yang akan mempengaruhi bentuk dan substansi dari organisasi pemilikan dan tingkah laku dari para pelaku ekonomi itu sendiri.

Ada beberapa nilai dasar yang dapat diturunkan dari keyakinan dan pandangan filosofis di atas. Pertama, nilai dasar kepemilikan. Konsep kepemilikan dalam Islam tidak sama dengan konsep kepemilikan dalam faham liberalisme seperti yang dikemukakan John Lock. Bagi John Lock, setiap manusia adalah tuan serta penguasa penuh atas kepribadiannya, atas tubuhnya, dan atas tenaga kerja yang berasal dari tubuhnya. ${ }^{9}$ Ini berarti kepemilikan yang ada pada seseorang adalah bersifat absolut. Oleh karena itu, untuk apa dan bagaimana dia menggunakan hartanya sepenuhnya adalah tergantung kepada dirinya. Ini tidak disetujui oleh Karl Marx. Pandangan tersebut, menurut dia, sangat berbahaya karena akan membawa kepada kehidupan yang eksploitatif dan penuh konflik. Untuk itu, agar tercipta suatu kehidupan yang baik (tidak ada konflik antar kelas) kata Marx, kepemilikan individual terutama kepemilikan terhadap alat-alat produksi harus dihapus karena inilah yang menjadi biang dan membuat kaum proletar atau buruh menderita selama ini. ${ }^{10}$

Berbeda dengan dua pandangan di atas, Islam mengakui kepemilikan individual. Bahkan di samping itu, Islam juga mengakui akan adanya kepemilikan oleh masyarakat dan oleh negara. Tetapi kepemilikan tersebut sifatnya tidaklah absolut, tetapi relatif. Apa artinya? Kepemilikan yang ada pada seseorang atau masyarakat atau negara tersebut bukanlah sepenuhnya milik dan hasil usaha mereka, tetapi itu adalah amanat dan kepercayaan dari Tuhan kepada mereka (Q.s. al-Ra'd [13]: 28, al-Fajr [89]: 16) yang harus dijaga, dipelihara, dan dipergunakan dengan sebaik-baiknya (Q.s. al-Mâ'idah [5]: 7). Oleh karena itu, seseorang tidak boleh menghambur-hamburkan hartanya (Q.s. al-Isrâ' [17]: 26-

${ }^{9}$ K. Bertens, Pengantar Etika Bisnis, (Yogyakarta: Penerbit Kanisius, 2000), Cet. V, h. 111-122.

${ }^{10}$ Paham komunisme memiliki konsep bahwa kepemilikan individual benar-benar dihapus sama sekali dan diganti dengan kepemilikan oleh negara. Kalau dalam sosialisme, individu masih boleh memiliki kekayaan selain alat-alat produksi penting. 
27) dan atau mendiamkan hartanya (Q.s. Muhammad [47]: 38). Karena hal itu akan kehilangan fungsi sosialnya dan akan kehilangan multiplier effect dan maslahat dari kehadiran hartanya tersebut.

Kedua, nilai dasar kebebasan. Dalam ekonomi kapitalisme, individu diberi kebebasan yang seluas-luasnya untuk memanfaatkan atau tidak memanfaalkan harta yang dimilikinya. Juga untuk masuk atau tidak masuk ke dalam pasar baik sebagai produsen, distributor atau konsumen. Dalam bahasa yang lebih ekstrem tidak ada yang bisa membatasi kebebasan seorang individu kecuali dirinya sendiri. Hal ini tidak dapat diterima oleh faham sosialisme-komunisme. Mereka melihat kebebasan yang seperti itu akan membawa kepada anarkisme. Oleh karena itu, kebebasan tersebut harus ditundukkan untuk kepentingan bersama. Di dalam Islam kebebasan manusia sangat dihormati. Namun, kebebasan tersebut bukanlah tidak ada batasnya. Hal-hal tersebut direstriksi oleh ahkâm alSyarîh atau hukum-hukum dan ketentuan-ketentuan agama. ${ }^{11}$ Jika hal itu dilanggar maka menjadi kewajiban bagi negara untuk ikut campur.

Ketiga, nilai dasar keadilan. Keadilan yaitu memberikan setiap hak kepada para pemiliknya masing-masing tanpa melebihkan dan mengurangi. ${ }^{12}$ Persoalannya sekarang, siapakah yang berkompeten untuk menentukan hal tersebut? Dalam sistem sosialisme dan komunisme, hal itu menjadi otoritas negara, dalam sistem kapitalisme menjadi otoritas individu. Sedangkan dalam sistem ekonomi Islam, hal itu menjadi otoritas dan kewenangan Tuhan (Qs. 42; 17). Konsekuensi konsep ini dalam kehidupan tentu akan menimbulkan perbedaan. Misalnya dalam sistem sosialisme-komunisme yang menjadikan kebersamaan dan kesamarataan sebagai nilai utama, maka kebutuhan dijadikan dasar untuk menentukan sesuatu itu adil atau tidak. mereka berpendapat bahwa suatu masyarakat akan dikatakan adil jika kebutuhan semua warganya terpenuhi, seperti kebutuhan akan sandang, pangan, (dan) papan. ${ }^{13}$ Jika hal itu tidak terjadi maka berarti telah terjadi praktik kezaliman.

Dalam kapitalisme liberal, konsep keadilan tidaklah didasarkan kepada kebutuhan tetapi kepada kebebasan itu sendiri. Menurut konsep ini, adilnya suatu perolehan itu haruslah dibagi menurut usaha-usaha bebas dari individuindividu bersangkutan. Yang tidak berusaha tidak mempunyai hak pula untuk

\footnotetext{
11‘Adnân Khâlid al-Turkmânî, al-Madzhab al-Iqtishâdî al-Islâmî, (Riyâdh: Maktabah al-Sawadi, Jâmi'ah al-Imâm Muhammad ibn Su'ûd al-Islâmiyyah, t.th), h. 144.

${ }^{12}$ Yusut Qardhawi, Peran dan Nilai Moral dalam Perekonomian, (Jakarta: Robbani Press, 1995), h. 390.

${ }^{13}$ K. Bertens, Pengantar Etika Bisnis, (Yogyakarta: Penerbit Kanisius, 2000), Cet. V, h. 99.
} 
memperoleh sesuatu. ${ }^{14}$ Oleh karena itu, di dalam teori keadilan liberalis ini, membantu orang yang miskin atau dalam kesulitan sebagai sesuatu yang sangat tidak etis karena mereka mendapatkan sesuatu tanpa mengeluarkan air keringat sendiri. ${ }^{15}$ Sementara dalam Islam keadilan dilihat dari sisi kesesuaian dan ketidaksesuaiannya dengan ajaran agama seperti yang telah digariskan di dalam Alquranan dan Sunah. Oleh karena itu, kepedulian kepada orang yang miskin dan tertindas dalam Islam akan dilihat sebagai sebuah praktik keadilan karena hal demikian diperintahkan oleh agama (Q.s. al-Tawbah [9]: 61). Sementara mengabaikan hal itu merupakan sebuah praktik kezaliman (Q.s. al-Mâ'ûn [107]:1-3).

Keempat, nilai dasar keseimbangan. Sistem ekonomi kapitalisme lebih mementingkan individu dari masyarakat sehingga orang merasakan harga diri dan eksistensinya. Orang diberi kesempatan untuk mengembangkan segala potensi dan kepribadiannya, akan tetapi pada umumnya, individu tersebut terkenal penyakit egoistis, materialistis, pragmatis, dan rakus untuk memiliki segala sesuatu. ${ }^{16}$ Hal itu didorong oleh pandangan dan pola hidupnya yang individualistis dan berorientasi kepada profit motive. Sementara sistem sosialis lebih mementingkan masyarakat dari individu. Roh sistem ini sangat berprasangka buruk terhadap individu. Oleh karena itu, pemasungan terhadap naluri ingin memiliki dan menjadi kaya harus dilakukan. Akibat dari kedua sistem ini terjadilah ketegangan, disharmoni, dan ketidakseimbangan antara kepentingan individu dan kepentingan masyarakat.

Dalam Islam, masalah keseimbangan ini sangat mendapat tekanan dan perhatian. Tidak hanya keseimbangan antara kepentingan orang perorang dengan kepentingan bersama, antara kepentingan dunia dan akhirat, jasmani dan rohani, akal dan rohani, idealisme dan fakta, tetapi juga keseimbangan dalam modal dan aktivitas, produksi dan konsumsi serta sirkulasi kekayaan. Oleh karena itu, Islam melarang dan mencegah terjadinya akumulasi dan sirkulasi kekayaan hanya pada segelintir orang, seperti terkandung dalam makna surah al-

${ }^{14}$ K. Bertens, Pengantar Etika Bisnis, h. 100.

${ }^{15}$ Bagi Malthus persoalan ini tidak hanya berdimensi etis tetapi juga berdimensi rasional karena menurut pendapatnya jika orang miskin tadi dibantu dan sudah mulai hidup sejahtera maka libido seksualnya akan tersalurkan. Mereka mempunyai anak yang banyak dan pada titik tertentu, kata Malthus pertumbuhan penduduk kan menurut deret ukur $(1,2,4,8,16)$ dan pertambahan produksi makanan menurut deret hitung (1,2,3,4, dst.). Maka, jumlah populasi akan melebihi jumlah persediaan makanan yang ada sehingga masyarakat kembali miskin. Lihat Steven Pressman, dalam bukunya, Fifty Major Economist.

${ }^{16}$ Yusuf Qardhawi, Peran Nilai dan Moral dalam Perekonomian Islam, (Jakarta: Robbani Press, 1997), Cet. I, h. 84. 
Hasyr [59]: 7) yang artinya supaya harta itu jangan hanya beredar di antara orangorang kaya saja di antara kamu. Bila terjadi kesenjangan kepemilikan yang tajam antar individu kaitannya dengan pemenuhan kebutuhan-kebutuhannya, maka berarti telah terjadi praktik kezaliman.

Untuk itu, negara harus turun melakukan intervensi agar keseimbangan ekenomi di tengah-tengah masyarakat dapat terwujud kembali. Begitu juga dalam hal pembelanjaan dan pengeluaran, Islam mendorong umat kepada berperilaku moderat, yaitu tidak isyrâf (boros) tetapi juga tidak bakhîl (pelit), dalam orientasi pembangunan, kebijakan yang diambil tidak boleh hanya menekankan kepada pertumbuhan (growth) tetapi juga kepada pemerataan (equity) agar tercipta keamanan dan ketentraman di tengah-tengah masyarakat (stability).

Kelima, nilai dasar persaudaraan dan kebersamaan. Dalam paham sosialisme-komunisme, persaudaraan dan kebersamaan merupakan nilai yang utama dan pertama. Untuk itu, agar nilai-nilai tersebut tidak rusak dan tidak terganggu maka kepemilikan individual yang menjadi penyebab terjadinya perselisihan dan persengketaan harus dihapuskan dan digantikan oleh negara. Negara yang mengatur produksi, distribusi, dan konsumsi masyarakat sehinga dengan demikian secara teoretis tidak akan ada kesenjangan sosial ekonomi dan permusuhan. Di dalam paham kapitalisme liberalisme hal ini tidak terlalu menjadi perhatian. Bagi mereka persaudaraan akan dapat terjadi seolah-olah secara otomatis di luar maksud para pelaku ekonomi itu sendiri, karena perekat dari persaudaraan itu bagi mereka adalah kepentingan. Hal ini berbeda dengan ajaran Islam. Kebersamaan dalam Islam merupakan indikator dari keberimanan seseorang (Q.s. al-Hujurât [49]: 10).

Nilai-nilai persaudaraan dan kebersamaan ini merupakan konsekuensi logis dari penunjukan manusia sebagai khalifah karena penunjukan tersebut bukan hanya untuk orang-orang tertentu saja tetapi adalah untuk semua orang (Q.s. al-Baqarah [2]: 30). Dengan demikian, seluruh manusia secara potensial di mata Allah dan memiliki status, kedudukan, dan martabat yang sama. Oleh karena itu, perbedaan ras, etnik, dan bahasa bukanlah menjadi variabel pembeda di mata Tuhan. Yang menjadi pembeda bagi Allah adalah keimanan dan ketakwaannya (Q.s. al-Hujurât [49]: 13).

Untuk itu, Islam melarang adanya praktik kezaliman dan ketidakadilan terhadap sesama dan adanya praktik-praktik eksploitasi sumber daya alam tertentu oleh seseorang atau kelompok tertentu. Hal tersebut akan merusak nilainilai persaudaraan dan kebersamaan yang digariskan Islam. Namun, kebersamaan yang dimaksud di sini juga harus dibingkai dengan kebersamaan etis yaitu suatu kebersamaan dalam kebaikan dan ketaqwaan, tidak dalam melanggar 
ketentuan-ketentuan agama (Qs. al-Mâ'idah [5]: 3). Hal ini secara ekonomis tentu mempunyai makna dan pengaruh yang positif terutama di dalam membangun hubungan kepercayaan (trust) dan kesetiaan (loyality) dalam bermuamalah dan akan menghindarkan rasa iri atau persaingan tidak sehat serta permusuhan antara sesama yang akhirnya akan merugikan semua pihak.

\section{Nilai-ilai Instrumental Ekonomi Islam}

Nilai-nilai dasar sebuah sistem ekonomi baru bisa dioperasionalkan hanya bila terdapat basis kebijakan (nilai instrumental) yang mendukung. Yang dimaksud dengan nilai instrumental ialah segala sesuatu yang akan menjadi persyaratan bagi pelaksanaan dan terlaksananya sistem tersebut.

Dalam sistem ekonomi kapitalis, nilai instrumental tersebut terletak pada nilai persaingan sempurna dan kebebasan keluar masuk pasar tanpa restriksi, informasi, dan bentuk pasar atomistik dari tiap unit ekonomi, pasar yang monopolisitik untuk mencegah perang harga dan pada waktu yang sama menjamin produsen dengan kemampuan untuk menetapkan harga lebih tinggi dari pada biaya marginal. Sedangkan dalam sistem Marxisme, semua perencanaan ekonomi dilaksanakan secara sentral melalui proses yang mekanistik, pemilikan kaum proletar terhadap faktor-faktor produksi diatur secara kolektif; proses iterasi dan kolektivitas ini adalah beberapa nilai instrumental yang pokok dari Marxisme. ${ }^{17}$

Dalam sistem ekonomi Islam ada beberapa nilai instrumental yang strategis yang mempengaruhi tingkah laku ekonomi seseorang, masyarakat, dan pembangunan ekonomi pada umumnya. Pertama, zakat. Zakat merupakan bagian dari harta yang harus dikeluarkan oleh seorang Muslim bila harta mereka telah mencapai nisab dan sudah memenuhi ketentuan-ketentuan yang ditetapkan oleh syariah (Q.s. al-Baqarah [2]: 2, 176), yang ukuran dan peruntukannya juga sudah ada ketetapannya dari Tuhan sendiri (Q.s. al-Tawbah [9 ]: 60).

Pasa masa awal Islam zakat dihimpun oleh negara dan merupakan sumber pendapatan utama negara. Zakat pada waktu itu benar-benar merupakan sarana utama untuk menciptakan keadilan sosial, politik, dan ekonomi. Aktivitas ini benar-benar berfungsi menciptakan persaudaraan dan kebersamaan di kalangan umat, karena dana zakat merupakan salah satu pilar penting dari sumber dana jaminan sosial. Adanya instrumen ini secara ekonomi tentu memiliki beberapa makna, yakni: (1) zakat mendorong terjadinya pendistribusian pendapatan dan kekayaan dari orang yang berpunya kepada orang yang miskin atau yang memerlukannya, sehingga kebutuhan pokok masyarakat terpenuhi dan

${ }^{17}$ Ahmad M. Saefudin, Studi Nilai-nilai Sistem Ekonom Islam, (Jakarta: Media Dakwah, 1984), h. 66 . 
kesenjangan ekonomi bisa dikurangi; (2) zakat secara langsung atau tidak tentu akan mempunyai pengaruh nyata terhadap tingkah laku konsumsi umat dan penciptaan lapangan kerja apalagi bila zakat tersebut dikelola melalui usahausaha produktif sehingga secara sosial, zakat dapat memberikan dampak bagi terciptanya keamanan masyarakat dan menghilangkan pertentangan kelas yang diakibatkan oleh perbedaan pendapatan yang tajam; (3) zakat dapat meningkatkan produktivitas dan daya beli masyarakat dan serta membendung inflasi.

Kedua, pelarangan riba. Nilai instrumental ini sangat terkait erat dengan pemberantasan praktik kezaliman dan ketidakadilan (Q.s. al-Baqarah [2]: 278279). Secara sempit penghapusan riba berarti penghapusan eksploitasi yang terjadi dalam utang-piutang maupun jual-beli (tetapi), secara luas penghapusan riba dimaknai sebagai penghapusan segala bentuk praktik ekonomi yang menimbulkan kezaliman atau ketidakadilan. ${ }^{18}$

Secara ekonomi, praktik riba jelas tampak tidak berpihak kepada full employment (terciptanya tenaga kerja penuh) karena sistem riba atau bunga jelas tidak memberi peluang kepada nasabah untuk masuk ke sektor-sektor usaha yang tingkat profitnya sama atau di bawah dari suku bunga yang ada. Akibatnya, peluang lapangan kerja menjadi tertutup dan rekruitmen terhadap tenaga kerja menjadi tidak bisa dilakukan. Praktik ini diperparah oleh perbankan konvensional yang tidak mau mengambil risiko rugi sehingga mereka meminta jaminan kepada para nasabahnya. Kebijakan ini dapat diterapkan kepada kaum yang berpunya karena merekalah yang memiliki jaminan.

Sementara itu, orang yang miskin meskipun secara teknis mereka lebih layak untuk mendapatkan kredit karena keahlian dan kemampuan yang dimilikinya. Namun, karena mereka tidak memiliki apa-apa untuk dijaminkan, maka mereka tidak bisa mendapatkannya. Hal ini akan berdampak kepada produktivitas dan efisiensi. Di samping itu sistem riba ini secara makro akan meningkatkan inflasi, karena tingkat suku bunga yang dikenakan kepada nasabah jelas akan meningkatkan biaya produksi sehingga secara keseluruhan harga akan naik (inflasi). Bila harga-harga secara umum meningkat, maka pasti ada kelompok masyarakat yang terpukul dan akan terkena dampak negatif dari inflasi tersebut yaitu orang yang berpendapatan rendah sehingga tidak mustahil mereka yang semula sebagai muzaki akan jatuh miskin. Hal ini disebabkan terjadinya kenaikan harga-harga yang menyebabkan mereka tidak mampu memenuhi kebutuhan-kebutuhan pokoknya.

${ }^{18}$ MB. Hendri Anto, Pengantar Ekonomi Mikro Islami, (Yogyakarta: Penerbit Ekonomi, 2003), Cet. I, h. 39. 
Ketiga, kerjasama ekonomi. Kalau dalam ekonomi kapitalis sangat ditonjolkan masalah kompetisi bebas, sehingga mereka melihat orang lain sebagai kompetitor atau pesaing yang harus ditundukkan. Sedangkan dalam sistem ekonomi sosialis terjadi sebaliknya. Sistem ini tidak mengenal persaingan karena segala-galanya sudah diatur oleh negara baik di tingkat produksi, distribusi maupun konsumsi. Tetapi berbeda dengan kedua sistem ekonomi di atas, sistem ekonomi Islam sangat dianjurkan adanya kerjasama dalam semua tingkat kegiatan ekonomi baik pada sektor produksi maupun distribusi dan konsumsi.

Kerjasama tersebut bisa dilakukan dalam bentuk syirkah, mudhârabah, dan/atau koperasi yang fungsinya, menurut Daud Ali, ${ }^{19}$ akan dapat menciptakan kerja produktif sehari-hari dari masyarakat (Q.s. al-Baqarah [2]: 190), meningkatkan kesejahteraan, mencegah kesengsaraan sosial (Q.s. Âli 'Imrân [3]: 103, alMâidah [5]: 3, al-Tawbah [9]: 71, 105 ), mencegah penindasan ekonomi dan distribusi kekayaan yang tidak merata (Q.s. al-Isrâ' [17]: 16, al-Hâqqah [69]: 25 37, 89 : 17-20,107 :1-7), dan melindungi kepentingan ekonomi lemah (Q.s. alNisâ' [4]: 5-10, al-Fajr [89]: 17-26 ). Dengan adanya kerjasama ini maka prinsip yang kuat membantu yang lemah (Q.s. al-Zukhruf [43]: 32) dan adanya pembagian kerja dan spesialisasi tentu bisa ditegakkan sehingga kebersamaan, keadilan, dan pertumbuhan serta pemerataan akan dapat diwujudkan.

Keempat, jaminan sosial. Islam memberikan jaminan terhadap tingkat dan kualitas hidup yang minimum (basic needs) bagi seluruh lapisan masyarakat (Q.s. al-Tawbah [9]: 6). Pentingnya jaminan sosial tersebut terkandung dalam ajaran-ajaran yang mengatakan bahwa: (1) manfaat sumber-sumber alam harus dapat dinikmati oleh semua makhluk Allah (Q.s. al-An'âm [6]: 38, al-Raḩmân [55]: 10); (2) Kehidupan fakir miskin harus diperhatikan oleh masyarakat terutama oleh mereka yang punya (Q.s. al-Dzâriyât [51]:19, al-Ma'ârij [70]: 24); (3) Kekayaan tidak boleh dinikmati dan hanya berputar di antara orang-orang kaya saja. (4) Berbuat kebaikanlah kepada masyarakat sebagaimana Allah telah berbuat baik kepadamu (Q.s. al-Qashash [28]: 77), antara lain dengan menyediakan sumber-sumber alam itu; (5) Seorang Muslim yang tidak mempunyai kekayaan harus mau dan mampu menyumbangkan tenaganya untuk tujuantujuan sosial (Q.s. al-Tawbah [9]: 79); (6) Seseorang janganlah menyumbang untuk kepentingan sosial dan juga untuk keperluan pribadi serta keluarga sebagai unit kecil masyarakat agar dipuji oleh orang lain (Q.s. al-Tawbah [9]: 262); (7) Jaminan sosial itu harus diberikan sekurang-kurangnya kepada mereka

${ }^{19}$ Mohammad Daud Ali, Sistem Ekonomi Islam, Zakat dan Wakaf, (Jakarta: UI Press, 1998), Cet. I, h.16. 
yang disebutkan dalam Alquran sebagai pihak-pihak yang berhak atas jaminan tersebut (Q.s. al-Baqarah [2]: 273, al-Tawbah [9]: 60 ), dan lain-lain. ${ }^{20}$

Dengan melaksanakan ajaran tentang jaminan sosial di atas berarti manusia di samping telah berusaha mendekatkan dirinya kepada Allah, membersihkan hartanya, dan membuang sifat riba dan tamak serta egoismenya, dan telah memberlakukan hartanya sesuai dengan ketentuan agama. Hal ini akan menciptakan kehidupan yang berkeadilan dan berkeseimbangan yang penuh dengan semangat persaudaraan dan kebersamaan.

\section{Peranan Negara}

Berbeda dengan sistem ekonomi kapitalisme yang sangat memproduksi peran pemerintah dan memberikan kebebasan yang sangat luas kepada para pelaku pasar (swasta) dan sistem ekonomi sosialisme yang mereduksi peran swasta dan memberikan peran yang teralu besar kepada pemerintah atau negara, sistem ekonomi Islam berada ditengah-tengah. Artinya Islam menghormati mekanisme pasar tetapi juga sekaligus memberikan peran kepada pemerintah untuk mendorong para pelaku ekonomi agar berbuat baik dan mencegah mereka untuk tidak berbuat munkar. ${ }^{21}$

Dengan demikian tidak terjadi distorsi alau pelanggaran aturan moral di pasar seperti adanya praktik penipuan, kecurangan, penimbunan dan lain-lain. Selain itu dapat mendorong bagi terciptanya pertumbuhan, pemerataan dan stabilitas ekonomi yang mantap. Di zaman awal Islam peran ini di laksanakan oleh sebuah lembaga independen yang dinamakan lembaga hisbah yang fungsi dan tugasnya seperti dikemukakan oleh A. A. Islahi adalah memerintahkan semua yang berada di bawah wewenangnya untuk melaksanakan salat Jumat, menunaikan salat wajib lainnya, menegakkan kebenaran, membayar kembali simpanan, melarang perbuatan buruk seperti berkata dusta, tidak jujur, mengurangi timbangan dan takaran, melakukan penipuan pada masalah industri, perdagangan, agama dan sebagainya. ${ }^{22}$

Ini artinya kehadiran pemerintah selain untuk menegakkan mekanisme pasar yang baik juga sekaligus untuk mengatasi kegagalan pasar itu sendiri. Semua itu tentunya akan sangat berpengaruh terciptanya kebebasan, keseimbangan, kebersamaan, dan keadilan di tengah-tengah masyarakat.

${ }^{20}$ Mohammad Daud Ali, Sistem Ekonomi Islam, Zakat dan Wakaf, h. 17.

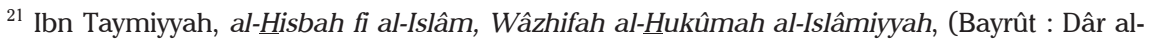
Fikr al-Lubnân, 1992), h. 15.

${ }^{22}$ A.A. Islahi, Konsepsi Ekonomi Ibnu Taimiyah, diterjemahkan oleh Anshari Thayib, (Surabaya: PT. Bina Ilmu, 1997), Cet. I, h. 242. 


\section{Penutup}

Sistem ekonomi Islam adalah sebuah sistem ekonomi tersendiri, bukan merupakan perpaduan dan atau campuran antara sistem ekonomi kapitalisme dan sosialisme, karena falsafah, nilai-nilai dasar, dan nilai-nilai instrumental dari sistem ekonomi Islam sangat berbeda dengan kedua sistem tersebut.

Sistem ekonomi Islam menempatkan manusia bukan sebagai sentral (antroposentrisme) tetapi sebagai hamba Tuhan (abid) yang harus mengabdi dan mengemban tugas yang dipercayakan-Nya sebagai khalifah. Untuk itu, dalam kegiatan ekonomi yang dilakukannya harus menjunjung tinggi nilai-nilai kepemilikan, nilai-nilai keadilan, kebebasan, keseimbangan, persaudaraan, serta kebersamaan sesuai ajaran agama agar tercipta sebuah tatanan hidup pribadi dan bermasyarakat serta bernegara yang baik.

Untuk itu, Islam telah meletakkan basis-basis kebijakannya berupa: (1) perintah membayar zakat kepada orang-orang yang mampu untuk para mustahiq; (2) melarang praktik-praktik riba (eksploitasi); (3) memberikan jaminan sosial kepada orang yang berhak menerimanya; (4) mendorong terciptanya kerjasama ekonomi tidak hanya antara individu dengan individu atau masyarakat dengan masyarakat lainnya tetapi juga kerjasama antar negara; (5) memfungsikan lembaga pemerintah untuk menjadi polisi sehingga sinergi para pelaku pasar akan dapat mewujudkan dan menciptakan kemakmuran, keamanan, dan keadilan di tengah-tengah masyarakat. []

\section{Pustaka Acuan}

\section{Buku:}

Anto, MB. Hendri, Pengantar Ekonomi Mikro Islami, Yogyakarta: Penerbit Ekonomi, 2003.

Turkmânî, al-, 'Adnân Khâlid, al-Madzhab al-Iqtishâdî al-Islâmî, Riyâdh: Maktabah al-Sawâdî, Jâmi'ah al-Imâm Muhammad ibn Su'ûd al-Islâmiyyah, t.th..

Ali, Mohammad Daud, Sistem Ekonomi Islam, Zakat dan Wakaf, Jakarta: UI Press, 1998.

Bertens, K. Pengantar Etika Bisnis, Yogyakarta: Penerbit Kanisius, 2000.

Chapra, M. Umer, Islam dan Tantangan Ekonomi, Islamisasi Ekonomi Kontemporer, diterjemahkan Nur Hadi Ihsan dan Rifki Amar, Surabaya: Risalah Gusti, 1999.

Islahi, A.A., Konsepsi Ekonomi Ibnu Taimiyah, diterjemahkan oleh Anshari Thayib, Surabaya: PT Bina Ilmu, 1997.

Qaradhawi, Yusut, Peran dan Nilai Moral dalam Perekonomian, Jakarta: Robbani Press, 1995. 
Rachbini, Didik J., Ekonomi Politik, Paradigma, dan Teori Pilihan Publik, Jakarta: Ghalia Indonesia, 2002.

Saefudin, Ahmad M., Studi Nilai-nilai Sistem Ekonom Islam, Jakarta: Media Dakwah, 1984.

Surbakti, Ramlan, Memahami Ilmu Politik, Jakarta: Penerbit PT. Gramedia Widiasarana Indonesia, 1992.

Ibn Taymiyyah, al-Hisbah fi al-Islâm, Wazhîfah al-Hukûmah al-Islâmiyyah, Bayrût: Dâr al-Fikr al-Lubnân, 1992.

\section{Media Massa:}

Kompas, 15 September 1992

Kompas, 20 Januari 1993 